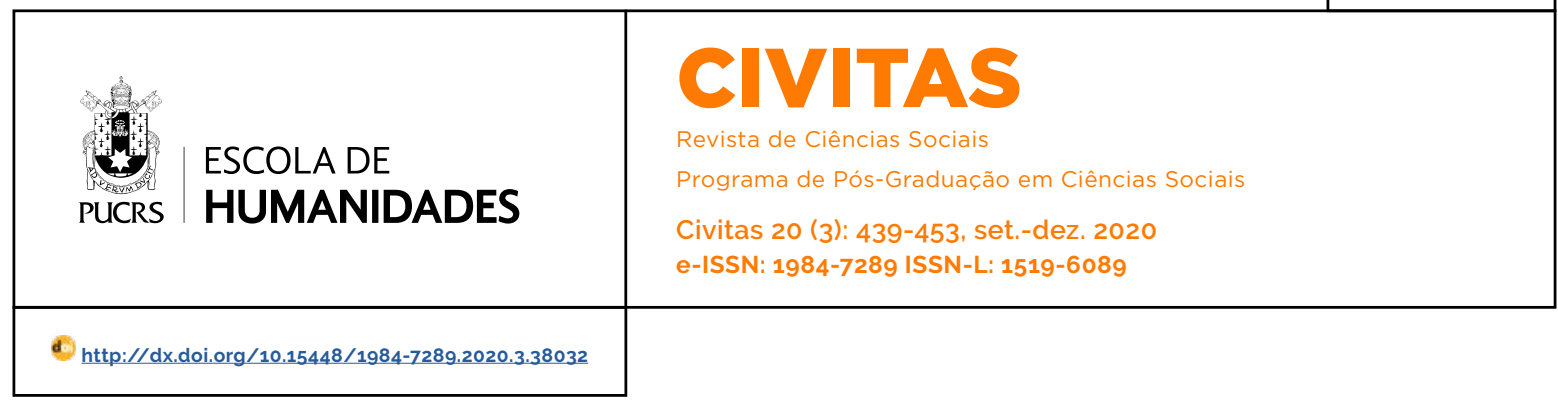

DOSSIER: FIGHT AGAINST CORRUPTION: STATE OF THE ART AND ANALYSIS PERSPECTIVES

\title{
Anti-corruption protests, alliance system and political polarization
}

\author{
Protestos anticorrupção, sistema de alianças e polarização politica \\ Protestas anticorrupción, sistema de alianzas y polarización política
}

\section{Wilson José Ferreira de Oliveira ${ }^{1}$ \\ orcid.org/0000-0001-8105-8885} etnografia.politica@gmail.com

Received: 8 May 2020

Accepted: 2 June 2020 Published: 23 Dec. 2020

\section{(c) (1)}

Artigo está licenciado sob forma de uma licença Creative Commons Atribuição 4.0 Internacional.
Abstract: The fight against corruption has become, in recent years, one of the main international causes. Many studies have been done on the effects and consequences of corrupt and corrupting practices for the political system and for the general society. However, there are still few who are dedicated to analyzing the conditions and dynamics of the fight against corruption as a public and international cause and its consequences and impacts on national political systems. Therefore, the objective of this article is to examine the emergence and spread of anti-corruption movements and protests in Brazil, between 2013 and 2018. I aim to demonstrate that the emergence and development of anti-corruption protests and mobilizations in this period are related to the crisis and collapse of the "alliance system" between the main political leaders and organizations, becoming a political resource to recompose and change such alignments. This analysis shows the relevance of the "political dimension" to understand the process of emergence and the development of protests and mobilizations against corruption.

Keywords: Anti-corruption movement. Protests. Alliance system.

Resumo: A luta contra a corrupção tornou-se, nos últimos anos, uma das principais causas internacionais. Muitos estudos têm sido feitos sobre os efeitos e consequências das práticas corruptas e corruptoras para o sistema político e para a sociedade geral. Todavia, ainda são poucos os que se dedicam à análise das condições e das dinâmicas de emergência da luta contra a corrupção como uma causa pública e internacional e de seus desdobramentos e impactos sobre os sistemas políticos nacionais. Diante disso, o objetivo deste artigo é examinar o surgimento e a disseminação de movimentos e protestos anticorrupção no Brasil, entre 2013 e 2018. Trata-se de demonstrar que a emergência e o desenrolar de protestos e mobilizações anticorrupção neste periodo estão relacionados à crise e colapso do "sistema de alianças" entre as principais organizações e lideranças politicas, tornando-se um recurso político para recompor e alterar tais alinhamentos. Essa análise mostra a relevância da "dimensão política" para compreender o processo de emergência e de desenvolvimento de protestos e mobilizações contra a corrupção.

Palavras-Chave: Movimento anticorrupção. Protestos. Sistema de alianças.

Resumen: La lucha contra la corrupción, en los últimos años, se ha convertido en una de las principales causas internacionales. Se han realizado muchos estudios sobre los efectos y consecuencias de las prácticas corruptas y corruptoras para el sistema político y para la sociedad en general. Sin embargo, todavía son pocos los que se dedican al análisis de las condiciones y el surgimiento de la lucha contra la corrupción como causa pública e internacional y sus consecuencias e impactos en los sistemas políticos nacionales. Por lo tanto, el objetivo de este artículo es examinar el surgimiento y la propagación de movimientos y protestas anticorrupción en Brasil. entre 2013 y 2018. Es demostrar que el surgimiento y desarrollo de protestas y movilizaciones anticorrupción en este periodo están relacionados con la crisis y colapso del "sistema de alianzas" entre las principales organizaciones y líderes politicos, convirtiéndose en un recurso político para recomponer y cambiar estas alineaciones. Este análisis muestra la relevancia de la "dimensión política" para comprender el proceso de emergencia y el desarrollo de protestas y movilizaciones contra la corrupción.

Palabras clave: Movimiento anticorrupción. Protestas. Sistema de alianzas. 


\section{Introduction}

In recent years, the fight against corruption has become a real international cause. Like other similar causes (Environment, Human Rights, Domestic Violence, etc.), it became the subject of conferences and meetings of international organizations, of the development of indicators to measure the incidence level of corruption in different countries, as well as the formulation of measures and actions to cure this disease that affects different societies today. As Bratsis $(2013,7)$ points out,

[...] the idea of corruption has become so universal and unquestionable, so encrusted in several common meanings, that its determinations, historical specificities and social functions remain hidden.

Therefore, most works investigating the phenomenon of corruption start from an "anticorruption discourse" that takes for granted its existence and even its recurrence in some countries. Thus, they use it as a sort of explanation for "poverty", "delay" and the political and economic "instability" of such countries (Heidenheimer, Johnston, and Levine 1989; Eigen 2008; Bukovansky 2006; Bratsis 2014). In this way, many studies have been done on the effects and consequences of corrupt and corrupting practices for the political system and for the general society. A similar perspective is grounding those approaches that search the historical, political and cultural causes of the existence of corruption in several nations and their consequences and effects for the functioning of the State, the political and economic institutions, as well as the political system and more broadly society (Briquet 2009; Avritzer 2012; Andersson and Heywood 2010). Also in those works that use an ethnographic approach to the phenomenon, in the sense of apprehending the political and cultural conceptions and practices that support them, the existence of corruption as a "fact" and a "reality" is not questioned, emphasizing, instead, as It is part of a set of native grammars and practices typical of that society. Such assumption is present even in those analyzes that show the problems and effects of the ways of combating corruption through "large media operations" and that show how such "operations" lead to a greater diversification and dissemination of corrupt and corrupting actors and practices, instead of competing for its decrease or even elimination.

In view of this, it is possible to understand why there are still few works that take as their first object of analysis the very social and political construction of corruption as a public problem and which are dedicated to the analysis of the conditions and dynamics of its emergence as a public and international cause, as well as its developments and impacts on national political systems (Bratsis 2013. 2014: Sampson 2010, 2015). Perhaps, for this reason, research and theories on social movements have paid little attention to anti-corruption movements, in the same way that studies on corruption are rarely linked to analyzes of mobilizations against corruption (Della Porta 2017b).

Thus, one of the problems that still deserves further study of corruption studies is the relationship of corrupt and corrupting practices to this dynamic of international and universal imposition of the fight against corruption. In order to enter into this type of concern, this article intends to put into practice the understanding of the relationships between national anticorruption protests and mobilizations and the dynamics of internationalization of corruption as an international public cause. In other words, it is a question of understanding the relationships between this process of internationalization of the issue of corruption and the emergence of mobilizations, events and protests against corruption at the national and local levels. When and under what social and political conditions, corrupt and corrupting practices emerge as a problem for the organization and functioning of the national political system? What are the social, political and cultural conditions and processes that concretely link denunciations of corruption at the national level and the diffusion of anti-corruption campaigns at the international level? How are these relations based on ongoing changes both in the national political system and in international 
relations? What are its consequences for the dynamics of organization and functioning of the national political system and its relations with the international sphere? What are the effects of this for the transformation of conceptions, meanings and understanding of corrupt and corrupting practices and the procedures and measures to combat it?

To address issues like this, we took as a first object of analysis the process of social construction of the fight against corruption as a public cause, taking as reference the analysis of the emergence and dissemination of anti-corruption movements and protests in Brazil, between 2013 and 2018. ${ }^{2}$ Contrary to the versions that preset corruption as a result of political and institutional dysfunction, it was a question of placing at the center of the analysis "the dynamics of emergence and configuration of the collective action itself" (Cefaï 1996) to fight corruption: apprehend its forms of emergence and development, instead of explaining it by something that preexists, that precedes or surpasses it.

It is, therefore, a matter of taking the definition of corrupt and corrupting practices in their relations with the process of social construction of the anti-corruption struggle as a public and international cause, consequently, with the very national conditions and dynamics of emergency and configuration of the political action to fight corruption. In this sense, it is intended to demonstrate that the emergence and development of anti-corruption protests and mobilizations in this period are related to the crisis and the collapse of the "alliance system" between the main political organizations and leaders, becoming an important political resource to change and recompose such alignments.

To account for this, the article is divided into two main parts. Firstly, it is intended to show that the protests in "June 2013" constitute an important milestone in articulating a series of demands related to the dynamics of the Brazilian political system with a global wave of anti-corruption protests. Secondly, it is a question of examining the consequences of anti-corruption protests on the emergence and consolidation of "conservative", "liberal" and "authoritarian" agendas, groups and leaders in the political spectrum.

This type of approach aims to demonstrate the relevance of the political dimension to understand the process of emergence and the development of protests and mobilizations against corruption and its impacts on the political system. In this sense, this analysis of the conditions and dynamics of emergency and diffusion of anti-corruption protests and mobilizations constituted a relevant path for a better understanding of certain transformations underway in Brazilian society and politics.

\section{The international anti-corruption movement, "The June Journeys" and the struggle for "more"}

The fight against corruption has a long history in Brazilian politics, dating back to the fifties of the twentieth century (Silva 2017), when President Getúlio Vargas became the target of political complaints in the news media (radio and print newspapers), unfolding it in a serious institutional crisis and in the suicide of the president himself. Thereafter, cases that went public and were the subject of parliamentary commissions during the 70-90s are recurrent (Bezerra 1995). In the 1990s, accusations of corruption again led to the impeachment of then president Fernando Collor de Melo. In 2005, it was the turn of President Luís Inácio Lula da Silva, whose denunciations of corruption occupied most of the news in the media, in a long process also known as "Big Monthly" (extended until 2012). And in 2015 and 2106, President Dilma Rousseff, who was also the subject of an impeachment process. In the midst of these most notorious cases, thousands of situations involving politicians and entrepreneurs both at the federal, state and municipal levels.

Regarding the recurrence of these complaints,

\footnotetext{
This article is based on a series of researches that I have been developing for a long time on the transformations of collective action associations and the dynamics of political participation in the defense of diverse public causes. More specifically, it is the first result of a research on the anti-corruption movement that I started in my post-doctorate at Scuola Normale Superiore de Firenze under the tutelage of Professor Donatella Della Porta. I thank her very much for attention and suggestions for my research.
} 
there are a number of elements that both distinguish and approximate them. On the one hand, a clear change in the political-institutional spheres where cases are judged and condemned: at first, the Parliamentary Inquiry Commissions (CPI) (Bezerra 1995, 2017; Silva 2017); secondly, the legal sphere. Unlike the previous cases, this time the daily news from print and television newspapers, weekly magazines and social media (blogs, websites, Facebook, etc.) were based on revelations and statements by judges, prosecutors and members of the judiciary who were part of what became known as the "Carwash" operation. On the other hand, a strong continuity in terms of the predominance of denunciations, judgment and condemnation in the media: initially, radio, printed and television newspapers, weekly magazines; in the last cases in addition to these the strong presence of blogs, YouTube, websites, Facebook, Twitter etc. A strong continuity, also, in terms of how denunciations and corruption itself emerge as a public problem: in the most different cases, it is directly related to conflicts and ruptures in political relations between the main leaderships involved. This allows us to understand how, from the beginning, the political uses of complaints and the fight against corruption are defined: as a considerable resource in conflicts and disputes between the main political groups; or more precisely, as an important tool for changing political groups in the power of the state.

Amid these differences and continuities, the wave of protests that started in 2011, in several countries, constituted an important milestone in the emergence and diffusion of a new anticorruption paradigm (Della Porta 2017a, 2017b). In Brazil, it was the massive protests of 2013 also called "The June Journeys" that enabled a greater articulation between this new definition of corruption and a series of demands and discontent that were ongoing at the national level (Nobre 2013a, Mendes 2017; Alonso and Mische 2017; Tatagiba and Galvão 2019). Undoubtedly, this constitutes one of the main characteristics that differentiate recent mobilizations and actions to combat corruption from previous ones: its greater articulation with the international anti-corruption movement (Della Porta 2017b).

For this reason, the wave of protest that started in 2013 can be seen as a kind of catalyst for the recent changes in the conditions and dynamics of using the fight against corruption as a public cause in Brazil. In this sense, the analysis of the 2013 protest events and their consequences in the mobilizations for the impeachment of President Dilma Rousseff and in the 2018 elections, constitutes a relevant way to apprehend how corruption, which currently presents itself as a cross-cultural category, is apprehended and translated at the domestic or national level. This is because the emergence and transformations of anti-corruption protests and mobilizations in Brazil bring to light relevant elements for understanding the native conceptions and grammars of politics and democracy, the principles and dynamics of organization of the political system itself, as well as the contexts and of the logic of political action put into practice by different social actors. Such aspects are essential for a better understanding of the so-called "Brazilian crisis", as well as its relationships with changes that have occurred and are still underway in the political system and democracy in Brazil.

The 1990s were a milestone in the emergence of an anti-corruption discourse centered on notions of "good governance" that preached "deregulation and the reduction of state spending" [...], "Privatization, deregulation and liberalization have been seen as main cures for the disease of corruption" (Della Porta 2017b, 663). This speech was supported and disseminated by organizations, financial institutions, agencies and transnational organizations through international commissions, conferences, campaigns and treaties to combat this threat (De Sousa, Hindess, and Larmour 2010; Sampson 2010). In this regard, the Italian case is extremely relevant, since it was from this country that the debate on the fight against corruption gained international visibility. It was shortly after the international outbreak and diffusion of the Italian case (1992) that the structuring of a true "international anti-corruption industry" began (de Sousa, Hindess, and Larmour 2010; Sampson 
2010, 2015; Bratsis 2014; Della Porta 2017b). Significant to this is the fact that the emergence of a set of transnational anti-corruption decisions, actors and institutions began in the mid-1990s (Sampson 2010; Favarel-Garrigues 2009; Bratsis 2014: Della Porta 2017b), immediately after the emergence and spread of the "Mani pulite" case. "Anti-corruption packages" have been indicated as one of the "latest innovations of global capitalism", constituting a platform for the imposition of new global morality, while serving as a channel for constant readjustments of global capitalism by making ethics and "management reputation" as a corporate priority as valuable as cost accounting (Sampson 2015; Della Porta 2017b).

The wave of protests that emerged in 2011 brings up another anti-corruption paradigm. Contrary to the domination of the free market, neoliberalism and deregulation related to previous notions of "good governance", the criticism is now directed at the "corruption of democracy" produced by neoliberalism itself due to the growing collusion between the power of the oligarchies, the financial and business world and politicians (Della Porta 2017b). Denouncing the corruption of the ruling elites, the immorality and corruption of the system, the monopoly of politicians and greedy businessmen, etc., such protests present corruption as a "blatant example and cause of inequality": the high levels of enrichment of the " $1 \%$ " at the expense of the " $99 \%$ " suffering, it is a clear sign of the system's corruption, injustice and immorality. Therefore, they call for "more" transparency, democracy and freedom, through participatory and horizontal anti-corruption policies and the creation of control mechanisms by the citizens themselves (Della Porta 2017b).

In Brazil, it was in the so-called "The June Journeys" in 2013 that there was a greater articulation with this new anti-corruption paradigm, expressing discontent and dissatisfaction both from sectors that supported the then PT government, but who wanted to move forward with reforms and the quality of public services (Della Porta 2017b). As for those more conservative and authoritarian who invoked a return to "nationalism", conservative agendas and "ethics in politics" and who called for an end to "PT corruption" (Alonso and Mische 2017; Mendes 2017; Tatagiba and Galvão 2019). Therefore, such protests were supported by a diverse and heterogeneous public such as organized supporters, neighborhood associations, youth, the elderly, families, etc. Many of these without previous activism, were based on recruitment via friendship, work and family networks, now associated with virtual networks such as Facebook, YouTube, Blogs, etc, reaching a great repercussion in print, television and digital media (Alonso 2017; Mendes 2017; Oliveira and Santos 2017; Tatagiba and Galvão 2019).

In spite of this heterogeneity of demands, organizations and actors linked to the 2013 protests, the problem of "corruption" emerges in these protests as one of the main ingredients. On the one hand, that old Latin notion of "corruption of power" (Bratsis 2013) appeared associated with the complaint that the Workers' Party (PT) "sold itself" to the system by adhering to neoliberal policies and by allying itself with the elites of the business world and politics, betraying its own base (Della Porta 2017a; Mendes 2017). On the other hand, the most recent notion of political corruption (Bratsis 2013; de Sousa, Hindess, and Larmour 2010; Sampson 2010), which leads to a criticism of "opacity" in public spending and services and in overpricing for the realization of major construction. Against this background, discontent is directed at the quality of public services such as health, education, security, urban infrastructure, public transport, etc., and the overpricing of works for the Confederations Cup (2013), the World Cup (2014) and the Olympics (2016) (Alonso and Mische 2017; Alonso 2017).

Different analyzes have insisted on the plurality, "cacophony", "mosaic" etc, of the demands present in the protests and the coexistence of contradictory and diffuse arguments and feelings (Alonso and Mische 2017; Mendes 2017; Tatagiba and Galvão 2019). The slogan "it is not just 20 cents", it shows how widespread discontent and dissatisfaction are against the "system" itself, against its "immorality" and "opacity", in short, 
against "everything that is there" (Nobre 2013a). This "anti-system" sentiment will predominate throughout the cycle of anti-corruption protest, ending even in a series of mobilizations and protests against politics, parties, institutions, etc. Associated with this, this slogan also explains a certain centrality in the demand for "more" transparency, democracy, participation. In a way, this was what allowed the aggregation of the most different types of discontent and dissatisfaction around a kind of common cause: it is for more quality in infrastructure, health, education, public transport, democracy, participation etc. This perspective was associated with different repertoires of action and organizational practices. However, in the midst of this it is possible, according to Alonso and Mische (2017), to differentiate three main sets of networks and groups of activists linked to the protests: the autonomists, the patriots and the socialists.

Undoubtedly, one of the main protagonists of the 2013 protests was the "Movimento Passe Livre (Free bus ticket movement - MPL)" Mendes 2017; Alonso and Mische 2017). Its performance is linked to a broader context of disputes and transformations that resulted in a significant diversification of the defense of student causes, starting in the 2000s: changes in the participation of youth, in representative student organizations and in the relations between political parties, student movements and social movements (Oliveira and Santos 2017). This was also accompanied by the emergence of several organizations promoting and supporting demonstrations against the increase in public transport tickets, well before the year 2013 (Vainer 2013; Oliveira and Santos 2017; Tatagiba and Galvão 2019). More than a simple claim to avoid an increase of $\mathrm{R} \$ 0.20$ cents in the ticket of public transport, MPL's mobilizations and protests were part of a set of grammars, action repertoires and forms of organization based on networks of autonomist militancy (Alonso and Mische 2017; Alonso 2017; Mendes 2017).

The autonomist groups, although very diversified, have their origin in the protests of 2003 in Salvador (Bahia) and 2004 in Florianópolis (Santa
Catarina), which became known respectively as "Buzú uprising and free ratchet uprising". These had their main motto in the demand for public and free transport, as they were also articulated with the participation in the World Social Forum that took place in Porto Alegre since 2003 and that mobilized quite heterogeneous organizations and social movements, such as: socialist groups, anarchist collectives, gay and feminist movements, ecologists, the independent student movement and various human rights groups (Oliveira and Santos 2017). They are part of the emergence of new student defense organizations and the expansion of fissures within the scope of the representative organizations themselves, as well as within the organizations and leaders that supported the PT governments. They are the ones that come closest to the new anticorruption paradigm that emerged in the 2011 protest wave, raising flags and repertoires such as: non-partisanship, independence and autonomy in relation to political parties and State agents; refusal of traditional student organizations in view of their proximity to PT governments; rejection of centralization by state leaders and authorities and gender hierarchies; scenic performances, black clothing, burning turnstiles, etc. (Alonso and Mische 2017; Alonso 2017).

The groups called "patriots" constitute another equally relevant set of "translations" of this new anti-corruption paradigm in national political demands and agendas. It is made up of equally diverse organizations and actors whose origin goes well before the protests of 2013, or more precisely to the beginning of the 2000s, being, however, strongly driven in 2005 by the wide and ubiquitous coverage of newspapers, printed and television magazines, blogs, pages and digital media, etc., from the "Big monthly" scandal that was presented as "the biggest corruption scandal in the country" (Alonso 2019). They are also based on the articulation of networks of civic, business, religious and military activism, increasingly dissatisfied with the programs and actions of PT administrations, with an intense liberal, conservative and authoritarian association, 
with the participation and support of opposition parties to PT and with the presence in regular international events such as the Freedom Forum and links with "anti-globalization" organizations and extreme right-wing transnational groups (Alonso 2019). As Alonso (2019) and Tatagiba, Trindade, and Teixeira (2015) show, between 2003 and 2015, there was an immense proliferation of protests, demonstrations, organizations, movements, marches, fronts, campaigns, acts, etc., whose motto was the defense of liberal, conservative and authoritarian agendas and agendas as a counterpoint to the corruption directly associated with the administration of the Workers' Party (PT) and the successive corruption "scandals" that hit it: "Big monthly", Petrobras scandal - "Petrolão", etc. In this sense, they associated the refusal of political institutions, politicians, parties and the "elite itself as corrupt" with grammars and repertoires of action based on national symbols, colors and slogans, with the resumption of mobilization in the streets and of canonical events and places mobilization and with the definition of "corruption" as directly associated with the PT (Alonso and Mische 2017; Alonso 2017, 2019: Tatagiba, Trindade, and Teixeira 2015).

Finally, there are networks of organizations and groups of "socialist" activists. This is a group of organizations and leaders of movements, unions and small left parties, whose activities originate in the protests of the 1980s and 1990s, centered on criticism of capitalist exploitation, social inequalities and class exclusion and the defense of a redistributive and public policy agenda (Alonso and Mische 2017). During the PT governments they were included in the public administration or became influential in the formulation of policies, such as those related to ethnic, gender, educational and land issues, but also gained a voice with the institution of councils and participatory bodies (Abers, Serafim, and Tatagiba 2014). They had a greater international expansion with attempts to articulate with leftwing Latin American governments (Alonso 2019;
Santos Jr 2016). Leading organizations such as the workers union Central Única dos Trabalhadores (CUT) and the Movement of Homeless Workers (MSTS), among others, expressed a critical stance towards the government of then President Dilma Roussef through major mobilizations for popular reforms, two days before the "June 2013" explosion: urban reform, tax reform, democratization of communications, demilitarization of the police and political reform via an exclusive constituent" (Alonso 2017, 54). With red flags and banners, t-shirts and buttons with symbols of movements or parties, this repertoire and demands of the communities of socialist activists was widely shared to varying degrees by the popular, student, labor and landless movements.

In this way, the protests in "The June Journeys" are based on a series of contradictions, tensions, discontent and demands that had long been pressuring the political system, giving rise to diverse organizations, movements and mobilizations. It is, more properly, a contradiction between a significant "pluralism of political positions and tendencies" and "a shapeless multitude of political parties" that did not reflect these tendencies and positions, since they have become an "amalgamation of interests that is always in the government", whatever be it the government, making the party system a universe in which there is no room for polarizations of political positions, but only "amorphous accommodation" of opposing positions (Nobre 2013a). Add to that, the fact that one of the main parties, the PT, which was born and built as a reaction to this type of political and party logic, in 2013 had already become an establishment long ago, the pact with the "peemedebismo" 3 and achieved even more success than its predecessor in expanding a coalition "from A to Z" (Nobre 2013a). Therefore, "the multitude of demands, frustrations and aspirations" present in the protests of 2013 (Nobre 2013a) express a great diversification both in the networks of organizations and activists that supported the then government of the Workers' 
Party and those that from the beginning opposed. However, among networks of actors and such different demands, there are some common traits: a certain disenchantment, non-conformity and discontent against a political system that works under the basis of overwhelming supra-party majorities, for which there is neither situation nor opposition, closing all the forces of transformation and the possible channels of representation and transforming into a "homogeneous, amorphous and indistinct mass" (Nobre 2013a).

It is in this sense, from a rejection of the system as a whole, that one can better understand why it was a revolt against "everything that is there". The very intensification of the use of the internet and social networks in the mobilization and recruitment for protest events, can be better understood when one considers that such tools started, as Nobre (2013a) points out, the breaking of the political system's "armor" which functioned under the logic of "peemedebismo", dampening discontent, dissatisfaction and demands for transformation (Nobre 2013a). On one hand, because such uses expressed a certain discontent with the "monopoly of opinion formation and vocalization of dissatisfactions", by the traditional media. So that, the media itself was the target of constant attacks and slogans in the protests. On other hand, because they created their own channels for participation and facing the system, mobilizing, recruiting and taking disenchantment, discontent and dissatisfaction to the streets.

Thus, it can be seen that around the fight against the "opacity of the system", which constitutes one of the main ingredients of the wave of protests that emerged in 2011 (Della Porta 2017b), there are actors as diverse as the demands, the action repertoires and the performance logic that support it. However, in the Brazilian case, more than a revolt against the "immorality of the economic and capitalist system", it is more precisely a reaction to the continuity of a political system that is based on a "model of polarization and conflict" centered on the persistence of a "system of political cooptation" (Schwartzman 1988).

\begin{abstract}
A youth who grew up seeing a policy of backstage agreements, in which opposing political figures are always right in a large and unique condominium of power, has no models on which to base their own position, other than the rejection of the policy en bloc. Whoever was born from the 1990 s onwards, for example, did not see any real political polarization, but only false polarizations, with strictly electoral objectives (Nobre 2013a, 12).
\end{abstract}

\section{The strength of "anti", the collapse of the alliance system and polarization}

If the revolt "against everything that is there" constitutes the main theme of the protests of "June 2013", in the following years the fight against corruption will turn against a much more restricted part of the political system, which already appeared in the protests of 2013, but which will later become central: the Workers' Party and the alliance system that led to the electoral victory. This conversion of this revolt against "the system as a whole", against its "immorality" and "opacity", in a mobilization and fight against "PT's corruption" was neither automatic nor direct. It involved a long political work of articulation and mobilization, to make disenchantment and discontent "against everything" that was there, indignation against a specific party and the system of alliances that kept it in power. This work was carried out, basically, by "antipetist" organizations and groups, but it had important institutional allies in the mainstream media, in the legal, business, religious and military institutions and in the political-party system itself (Tatagiba, Trindade, and Teixeira 2015; Alonso 2019), as well as with widespread use of the internet and social networks as "channels for confronting the system" for recruitment and participation in protests and mobilizations (Nobre 2013a; Mendes 2017). This combination of an old network of actors opposed to the PT and relatively new recruitment and mobilization resources gradually made not only the conversion of "June 2013" into a legacy of "fighting antipetism", but also the confluence and realignment of actors and diverse organizations around both "liberal", "conservative" 
and "authoritarian" agendas and policies as well as "right-wing" movements and groups to replace political forces within the state itself (Miguel 2018).

In order to better visualize all this political work of converting the fight against corruption into an "anti-PT" mobilization, a second phase of the cycle of protests can be distinguished, which begins in 2014 and extends to the impeachment of President Dilma Rousseff. If in the first phase it was a diffuse discontent against "corruption", the "immorality" and "opacity" of the system, demanding more "transparency" and "democracy", in this second phase, the dissatisfaction was centered on complaints of corruption involving the PT ("Big monthly", Petrobrás scandal - "Petrolão") and its allies and the "misuse of the public machinery" of PT governments (Tatagiba, Trindade, and Teixeira 2015; Alonso 2019). Likewise, if in 2013 it was around "autonomist", "socialist" and "patriotic" groups that diverse organizations and groups disgruntled against the system were added; now it was the network of "antipetist" organizations and leaders that was at the forefront of articulating various organizations and "patriotic" groups ("liberal", "conservative" and "authoritarian"). Finally, if at the first moment of the cycle, the inclusion of demands that had been forgotten and the struggle for more democracy, participation, transparency, freedom, etc, was at stake, in this second moment, the tone is clearly contrary and strongly antagonistic, because what emerges with greater force is the anti: "petism", "partisanship", "leftism", "state", "stabilization", "alliance", "politics", etc, leading, sometimes, to a conception antagonistic or contrary to democracy itself.

This moment was characterized by the crisis and the collapse of the alliance system that supported the PT, by the emergence of new types of organizations and leaders and by a strong ideological polarization between "left" and "right". Such polarization initially emerged as an opposition between "socialists" and "patriots", through the campaigns "There won't be coup" and "Dilma out" (Alonso and Mische 2017). Subsequently, it was associated with a strong ideological antagonism between "PT" and "anti-PT" and was later generalized as part of a more general polarization between "left" and "right". "Antipetism" was one of the main ingredients in the manufacture and generalization of this antagonism: on the one hand, by enabling the confluence of the various "patriotic groups" based on a clear and pragmatic definition of the "common enemy"; and on the other, by allowing the consolidation and generalization of such antagonism in a more general polarization between "left" and "right".

\begin{abstract}
United by the common belief that it is necessary to take the Workers' Party out of power to solve Brazil's problems, these agents define PT members as terrorists, gangs, usurpers, communists and dictators. These channels are differentiated by the modes of action and various agendas underlying antipetism, among which are: resistance to policies to reduce inequality, criticism of human rights, reduction of the legal age, fight against corruption, disbelief in the political-democratic system, modification the status of armaments, increased repression of crime, defense of the traditional family, dissolution of the National Congress, impeachment, military intervention, economic guidelines independent of the State, and many others (Santos Jr. 2016, 82).
\end{abstract}

Thus, "antipetism" brought together different antagonisms that made it possible to articulate in a common discourse a series of actors, perspectives and heterogeneous demands (Santos Jr. 2016). On the one hand, an anti-party system based on a "negative partisanship" and a general denial of the party system itself given its weak representativeness in national politics and which materializes disproportionately in the figure of the PT due to "anti-corruption" bias, placing it as the one responsible for what is negative in Brazilian democracy. On the other hand, "antileftism" that rejects and combats the policies of the PT federal government, while rescuing ideological discourses of political traditions of the Brazilian right, such as those of "conservatism", "liberalism" and "anti-communism". Finally, an "anti-establishment" that expresses a strong denial of institutional political activity and the feeling of ineffectiveness and corruption of political institutions, resulting in great disbelief 
in democratic institutions themselves and a tendency to ignore the rules and legitimacy of the democratic regime (Santos Jr. 2016). These are the principles that are at the base of phrases and slogans such as: "The united people do not need a party!", "CorruPTos out", "The minority cannot silence the majority", "No more impunity! No more bandits", "Military intervention now!", "Flag, here, only from Brazil!", "Our flag will never be red, among many others" (Alonso 2019, 98).

Undoubtedly, the emergence of "Carwash operation" on March 17, 2014 and the intensification of the electoral process that led to the election of Dilma Rousseff that same year, constituted the two main factors for the expansion of "anti-PT groups" and for the expansion of their articulation with important institutional allies for mobilization and protest against the federal government, which culminated in the impeachment process of President Dilma Rousseff herself. The testimonies and daily exposures in the mainstream media of the scandals involving Petrobras, private companies, allied PT parties and the government itself boosted the "anti-PT" groups and leaders, as well as the street acts and "anti-corruption" protests now centered on PT corruption and in defense of the president's impeachment. This occurred based on the disclosure of data, analyzes and results of Carwash operation, through the outbreak of successive phases of the operation that were presented through collective interviews of the attorneys with the clear intention of mobilizing and maintaining the support of the population, to which were broadcast live in the media (Petrarca 2019). In this sense, it is observed that during the nine months of the operation's existence in 2014, 7 phases were triggered, while in 2015 this number increased to 14 and to 21 in 2016 (the year of Dilma Rousseff's impeachment). It was precisely in the years with the highest number of phases of Carwash operation (2015 and 2016) that the biggest demonstrations and protests against "PT corruption" and the government of Dilma Rousseff ${ }^{4}$ occurred. In addition to provoking the mobilization and support of the population, the conduct of investigations of the "operation" through daily exposure and dissemination in the mainstream media (radio, written press, TV) and social networks, of the deletions of those involved with the Petrobras scandals, equally important political function: fomenting daily threats, conflicts and crises between the main leaders and parties that constituted the support base of the PT government, to the point of causing the breakdown and collapse of the very system of alliances that supported the party in government (Bezerra 2018). In this sense, it can be said that Carwash operation played a structuring role in the emergence and acceleration of the crisis of the political system itself, both in offering opportunities for "anti-PT" protests and mobilizations and in weakening and causing the rupture of the alliance system current.

This support and support that the "antipetist" organizations and groups found in the legal and media institutions, was reinforced and expanded with the fierce political polarization that marked the dispute between PT and PSDB during the 2014 electoral process. First, favoring the union of all groups' antipetists, mainly in the second round of the elections, around the campaign of the PSDB candidate Aécio Neves in order to avoid the victory of Dilma Rousseff of the PT. Second, after the reelection of then President Dilma Rousseff, receiving funding from businessmen and opponents of the PT within the political-party system itself, as well as the support of the mainstream media, personalities, opinion leaders, microbloggers, columnists, political commentators opposing the government and some radical politicians based on the massive disclosure of scandals revealed by "Carwash" (Santos Jr. 2016; Rocha 2018). It is expressive of this articulation of the anti-corruption groups with the electoral process, the fact that during the 2014 elections the main groups and organizations, which later led the protests for the impeachment of the president in 2016, already called for acts and protests packed

4 It is worth noting that in the years after the impeachment there was a clear reduction in the number of phases triggered by the "Carwash" (Lava Jato): 10 in 2017, 10 in 2018 and 12 in 2019 
by the denunciations of corruption and in support of the candidacy of the PSDB party Aécio Neves (Tatagiba, Trindade, and Teixeira 2015).

In this sense, the strong political polarization that marked the electoral dispute, stimulated by the accusations of corruption in Petrobras that were disseminated by "Carwash" and received wide repercussion from the mainstream media, made it possible to unite not only the opposition forces to the government, but mainly, served as a basis. and again incentive for "antipetist" organizations and groups to invest heavily in a common enemy: the association between corruption and "PT", putting "PT out" and "Dilma out" as the only way to end corruption in Brazil in the short term. Therefore, immediately after the results that led to Dilma Rousseff's reelection were released, protests against the "elected president" and "PT government" resumed, called by "liberal", "conservative" and "authoritarian" organizations and with the important presence of "opposition figures" (Tatagiba, Trindade, and Teixeira 2015; Santos Jr. 2016). Thus, in 2015, after successive mobilizations and massive protests, the defense of impeachment became the main banner of such groups and organizations. Such protests demonstrated the strength of the mobilization of "antipetism", which also came to be associated with "anti-leftism", "anti-partyism", "anti-statism", rejection of the political class, etc. Thus, it is around the polarization between "left" and "right" that, at this stage, the different antagonisms between the different groups in conflict are articulated. As a result, it is also at that moment that the use of such categories as a form of identification, expression and political accusation emerges more strongly in political discussions and clashes (Miguel 2018).

Also with regard to the resources used for mobilization and recruitment for protests, it can be said that such organizations, groups and leaders have appropriated one of the main legacies of the wave of protests that emerged in 2013: the use of social media as a mobilization tool and recruitment for protest events (Nobre 2013a; Santos Jr. 2016; Mendes 2017; Alonso and Mische
2017). Thus, if in 2013 this use was more diffuse and widespread against the system as a whole, in this second phase social media became one of the main vehicles for agglutination, manifestation and action by organizations, groups and antiparty leaders from of a common agenda (Santos Jr. 2016). Thus, the use of the media started to focus on groups opposed to the PT and the government of Dilma Rousseff, demonstrating a great capacity to mobilize a significant number of people to protest against the governments "from PT" and "the left". However, this strong ability in the intensive use of social media (YouTube, Facebook, Twitter, Instagram etc.) in the militancy of these groups is not recent. On the contrary, it was, from the beginning, one of the main elements of activism put into practice by them, as long before 2013 and Dilma's reelection, or more precisely between the end of the first Lula government and the beginning of the second, they had already started to organize themselves, having as main resources discussion forums, blogs, websites and communities on the internet, bringing together groups and leaders who did not find "expression" in official politics or "representation" in institutional channels (Santos Jr. 2016; Rocha 2018).

Finally, a third phase can also be distinguished in this wave of anti-corruption protests that started in Brazil in 2013. It has as its starting point the impeachment of President Dilma Rousseff in 2016 and extends to the 2018 electoral process, with developments that go far in addition to the electoral process itself. Its main characteristics are the consolidation and expansion of "antipetist" organizations and leaders, the emergence of new movements and social organizations focused on the defense of change and "renewal" of the political and party system -"Renovabr" ("Renews BR"); "Movimento acredito" ("I Believe Movement"); "Now Movement" ("Movimento Agora" etc.) -, as well as the recomposition and realignment of forces around the figure of the presidential candidate Jair Bolsonaro. If the articulation of anti-corruption movements with the electoral and party political process was already visible in the previous phase, in this third stage of the protest cycle this will become 
a constant: leaders of organizations and movements that fought against "PT corruption" competing for municipal election positions, members of Carwash operation using social media to ask citizens not to vote for "corrupt candidates and politicians" and supporting "anti-PT" candidates.

A new phase undoubtedly emerges with the electoral victory of Jair Bolsonaro, his inauguration and exercise of the government, where many of those who were at the forefront of the anticorruption fight, including in the legal sphere and who were part of Carwash operation itself, start to integrate the cadres of the new government while others are elected and become part of its base, either in the senate or in the federal chamber. One of the most emblematic examples is the ex-judge Sérgio Moro himself. He was the main leader of Carwash operation and responsible for the arrest in 2018 of the main leader of the PT, former President Lula. With the victory of Jair Bolsonaro he left the judiciary to compose the new government as Minister of Justice and Public Security. Thus, it is increasingly clear that the antipetism associated with the anticorruption fight, has become the key driver of the mobilizations supported by the organizations and leaders that support the current president.

In general, in the Italian case, the fight against corruption had as its main basis a certain "independence", the growth of a "professional culture of the judiciary" and the "mission" of the judiciary (Pederzoli and Guarnieri 2010), even though through the mobilization of networks of informal relations with politicians and the media (Della Porta 2001). In contrast, in the Brazilian case, it is the intense articulation between the network of movements and "antipetist" organizations, the leadership networks of legal, media and party-political institutions and the strong political-electoral mobilization that enabled the conversion, consolidation and diffusion of "the fight against corruption" as a fight against the PT (Santos Jr. 2016). In this way, the mobilizations and protests against corruption in Brazil, initially aimed at increasing inequality and through greater "transparency", gradually became decisive political and electoral resources for the replacement of the parties and leaders who occupied a dominant position in the country. within the political system and the State by "antipetist" organizations, groups and leaders and by implemented government policies and programs linked to the agendas and agendas of such groups. In this sense, it can be said that the anti-corruption movement in Brazil has become a movement basically focused on the politicalelectoral modification of groups and leaders and policies that occupied a dominant position in the political and governmental system. This political party and electoral content had "antipetism" as one of the main catalysts, inasmuch as the "juxtaposition of Petism corruption" enabled the solidification of heterogeneous organizations, groups and leaders ("patriots", "liberals", "conservatives", "authoritarians", etc.), contrary to the Workers around what we might initially call a "right-wing movement" (Alonso 2019).

\section{Conclusion}

One of the main features of the protests' wave that began in 2011 in several countries was denouncing corruption as something that has a negative bearing on political and economic decisions and processes. Such protests are the starting point for understanding how the fight against corruption emerged and transformed in Brazil recently, which, due to a series of national political characteristics, occurs only in 2013 through the so-called June's Days, even though since the years from 2011, there is already a continuous growth of protests and street demonstrations in the country. Few studies have given due importance to this relationship between the wave of protests that started in 2011 and the spread of corruption as a global problem. This article is among those who seek to give more evidence to such a relationship. However, he intended to demonstrate that understanding this relationship necessarily involves examining the national political system itself: its principles and organizational dynamics.

In this sense, it was demonstrated that the protests in "June 2013" were an important milestone in the 
articulation between a series of disenchantments, discontent and dissatisfaction related to the very dynamics of the Brazilian political system and a new international anti-corruption paradigm that emerged in the wave of protests in 2011 Unlike the anti-corruption discourse centered on notions of "good governance" that emerged in the 1990s, the new international anti-corruption paradigm was geared towards criticizing the opacity of the economic and capitalist system and the "corruption of democracy" produced by neoliberalism itself, calling for more transparency, democracy and freedom. In the Brazilian case, more than a reaction against the "immorality" and "corruption" of the economic and capitalist system, these categories are used to express a revolt against the persistence of a political system that functioned on the basis of "political co-option" and "overwhelming supra party majorities", closing the possible channels of transformation and representation and assuming the form of a "homogeneous, amorphous and indistinct mass". This centrality of the revolt in the political system constitutes an important way to understand the meanings acquired in the fight against corruption in Brazil, the actions put into practice by the organizations and leaders of the anti-corruption movement, as well as the developments and impacts of such mobilizations on the political system itself.

The intersection of organizations and leaders who fought against corruption with diverse networks of actors and institutions linked to the political and electoral system itself has been, from the beginning, one of the main features of the anti-corruption movement in Brazil. This political party and electoral content of the fight against corruption in Brazil had, on the one hand, "antipetism" as one of the main catalysts, inasmuch as the juxtaposition of "corruption and petism" enabled the solidification of heterogeneous organizations, groups and leaders, contrary to the Workers' party, around a "right-wing movement". On the other hand, it led to the crisis and the collapse of the alliance system between the main organizations and political leaders, becoming a political resource to recompose and change these alignments. Such aspects made it possible to understand how mobilizations and protests initially against the inequalities and injustices of the system and of the elites in power and for more transparency, freedom and democracy, gradually became decisive political and electoral resources for the replacement of parties and leaders who held a dominant position within the political, electoral and governmental system by "patriotic", "liberal", "conservative" and "authoritarian" organizations, groups and leaders and by their government guidelines, policies and programs.

This analysis demonstrated the relevance of the "political dimension" to understand the processes of emergence and diffusion of public protests and protests. The characteristics and functioning dynamics of the political system are not secondary aspects in relation to the economic dimension that would be the priority. On the contrary, the Brazilian case exemplifies just how much it was the "crisis" of the political system that triggered a "crisis" over the economic system. On the other hand, it is in close relationship with the political system and with the electoral process that we will better understand how the social movements' own demands and logics of action arise and transform.

\section{References}

Abers, Rebecca, Lizandra Serafim, and Luciana Tatagiba. 2014. Repertórios de interação estado-sociedade em um estado heterogêneo: a experiência na era Lula. Dados 57 (2): 325-357. https://doi.org/10.1590/0011-5258201411.

Alonso, Angela. 2017. A política das ruas: protestos em São Paulo de Dilma a Temer. Novos Estudos Cebrap 37 (1): 49-58. https://doi.org/10.25091/ S01013300201700040006.

Alonso, Angela, and Ann Mische. 2017. Changing repertoires and partisan ambivalence in the new Brazilian protests: June 2013 in Brazil. Bulletin of Latin American Research 36 (2): 144-159. https://doi.org/10.1111/blar.12470.

Alonso, Angela. 2019. A gênese de 2013: formação do campo patriota. Journal of Democracy em Português 8 (1): 30.

Andersson, Staffan, and Paul M. Heywood. 2010. Anti-corruption as a risk to democracy: on the unintended consequences of international anti-corruption campaigns. In Governments, NGOs and anti-corruption: the new integrity warriors, edited by Luis de Sousa, Barry Hindess, and Peter Larmour, 33-49. London: Routledge. 
Avritzer, Leonardo, ed. 2012. Corrupção: ensaios e críticas. Belo Horizonte: UFMG.

Bezerra, Marcos Otavio. 2017. Corrupção e produção do estado. Revista Pós Ciências Sociais 14 (27): 99-130. https://doi.org/10.18764/2236-9473.v14n27p99-130.

Bezerra, Marcos Otavio. 1995. Corrupção: um estudo sobre poder público e relações pessoais no Brasil. Rio de Janeiro: Relume Dumará.

Bezerra, Marcos Otavio. 2018. Combate à corrupção, conflitos políticos e a tecedura do impeachment de Dilma Rousseff. $42^{\circ}$ Encontro da Anpocs. GT 10 Elites e Formas de Dominação. Caxambu: Anpocs.

Bratsis, Peter. 2013. La construcción de la corrupción o las reglas de separación y las ilusiones de la pureza en las sociedades burguesas. Ciencia Politica 8 (15): 4-25.

Bratsis, Peter. 2014. Political corruption in the age of transnational capitalism: from the relative autonomy of the state to the white man's burden. Historical Materialism 22 (1): 105-128. https://doi.or$\mathrm{g} / 10.1163 / 1569206 \mathrm{X}-12341334$

Briquet, Jean-Louis. 2009. Les conditions de félicité d'une croisade morale. Lutte anticorruption et conflits politiques dans l'Italie des années 1990. Droit et société 2 (72): 283-301. https://doi.org/10.3917/drs.072.0285.

Bukovansky, Mlada. 2006. The hollowness of anti-corruption discourse. Review of International Political Economy 13 (2): 181-209. https://doi. org/10.1080/09692290600625413.

Cefaï, Daniel. 1996. La construction des problèmes publics. Définitions de situations dans des arènes publiques. Réseaux 14 (75): 43-66. https://doi.org/10.3406/reso.1996.3684.

De Sousa, Luis, Barry Hindess, and Peter Larmour. 2010. Governments, NGOs and anti-corruption. The new integrity warriors. London: Routledge.

Della Porta, Donatella, ed. 2017a. Global diffusion of protest: riding the protest wave in the neoliberal crisis. Amsterdam: Amsterdam University Press.

Della Porta, Donatella. 2017b. Anti-Corruption from Below. Social movements against corruption in late neoliberalism. Partecipazione \& Conflitto 10 (3): 661-692. https://doi.org/10.1285/i20356609v10i3p661.

Della Porta, Donatella. 2001. A judges' revolution? Political corruption and the judiciary in Italy. European Journal of Political Research 39 (1): 1-21. https://doi. org/10.1111/1475-6765.00567.

Eigen, Peter. 2008. Removing a roadblock to development: transparency international mobilizes coalitions against corruption. Innovations: Technology, Governance, Globalization 3 (2): 19-33. https://doi.org/10.1162/itgg.2008.3.2.19.

Favarel-Garrigues, Gilles. 2009. Présentation. La lutte anticorruption, l'unanimisme international aux priorités intérieures. Droit et société 2 (72): 273-284. https://doi. org/10.3917/drs.072.0273.

Heidenheimer, Arnold J., Michael Johnston, and Victor T. le Vine, eds. 1989. Political corruption: a handbook. New Brunswick: Transaction Publishers
Mendes, Mariana S. 2017. Brazil's Popular Awakening June 2013. Accounting for the onset of a new cycle of contention. In Global diffusion of protest: riding the protest wave in the neoliberal crisis, edited by Donatella Della Porta, 59-84. Amsterdam: Amsterdam University Press.

Miguel, Luis Felipe. 2018. A reemergência da direita brasileira. In O ódio como politica: a reinvenção das direitas no Brasil, edited by Esther Solano Gallego, 1726. São Paulo: Boitempo.

Nobre, Marcos. 2013a. Choque de democracia: razões da revolta. São Paulo: Companhia das Letras. Kindle.

Nobre, Marcos. 2013b. Imobilismo em movimento: da abertura democrática ao governo Dilma. São Paulo: Companhia Das Letras.

Oliveira, Wilson José F. de, and Adrielma Silveira F. dos Santos. 2017. Eventos de protesto, repertórios organizacionais e dinâmicas de construção do transporte público e gratuito como uma causa pública. Dilemas - Revista de Estudos de Conflito e Controle Social 10 (3): 599-620.

Pederzoli, Patrizia, and Carlo Guarnieri. 2010. Italy: a case of judicial democracy? International Social Science Journal 49 (152): 253-270. https://doi.org/10.1111/j.1468-2451.1997.tbo0020.x.

Petrarca, Fernanda Rios. 2019. As operações "Lava Jato" e "Mani pulite" em perspectiva comparada. Relatório de Pós-doutorado em Ciência Política. UFS, Aracaju, Sergipe.

Rocha, Camila. 2018. O boom das novas direitas brasileiras: financiamento ou militância? In O ódio como politica: a reinvenção das direitas no Brasil, edited by Esther Solano Gallego, 48-52. São Paulo: Boitempo. Kindle.

Sampson, Steven. 2010. The anti-corruption industry: from movement to institution. Global Crime 11 (2): 261278. https://doi.org/10.1080/17440571003669258.

Sampson, Steven. 2015. The anticorruption package. Ephemera: Theory and Politics in Organization 15 (2):115-123

Santos Jr., Marcelo Alves dos. 2016. Vai Pra Cuba!!! A rede antipetista na eleição de 2014. Dissertação em Ciência Política, Universidade Federal Fluminense, Niterói, RJ, Brazil.

Schwartzman, Simon. 1988. Bases do autoritarismo brasileiro. Rio de Janeiro: Editora Campus.

Silva, Giuliana Monteiro da. 2017. Corrupção, narrativas de imprensa e moralidade pública nos anos 50: a conversão da corrupção em problema público no Brasil. Dissertação em Ciência Política, Universidade Federal Fluminense, Niterói, RJ, Brazil.

Tatagiba, Luciana, and Andreia Galvão. 2019. Os protestos no Brasil em tempos de crise (2011-2016). Opinião Pública 25 (1): 63-96. https://doi.org/10.1590/1807-0191201925163.

Tatagiba, Luciana Thiago Trindade, and Ana Cláudia Chaves Teixeira. 2015. Protestos à direita no Brasil (2007-2015). In Direita, volver! O retorno da direita e o ciclo político brasileiro, edited by Sebastião Velasco Cruz, André Kaysel e Gustavo Codas, 197-212. São Paulo: Fundação Perseu Abramo. 
Vainer, Carlos B., ed. 2013. Cidades rebeldes: passe livre e as manifestações que tomaram as ruas do Brasil. São Paulo: Boitempo Editorial.

Wilson José Ferreira de Oliveira

Associate professor of department of Social Sciences at Universidade Federal de Sergipe (UFS), Aracaju, SE, Brazil, and Postgraduate Program in Sociology. Doctorade in Social Anthrology at Universidade Federal do

Rio Grande do Sul (Ufrgs), Porto Alegre, RS, Brazil, and Pós-doctorate at Scuola Normale Superiore (SNS), Italy. 